\title{
Status and Distribution Study for Different Forms of Potassium in the Soils of Nignoti Village of Indore District of Western Madhya Pradesh, India
}

\author{
Jitendra Kumar Panwar and Shila P.K. Unni* \\ Department of Soil Science and Agricultural Chemistry, Rajmata Vijayaraje Scindia Krishi \\ Vishwa Vidyalaya, Gwalior, College of Agriculture Indore (M. P.), India \\ *Corresponding author
}

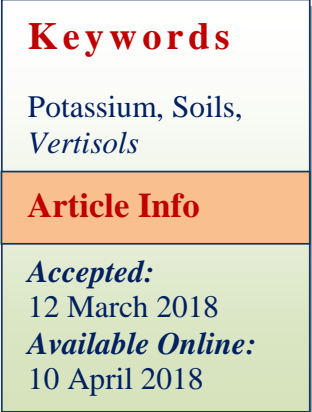

Potassium $(\mathrm{K})$, is an essential element for plant growth which exists in soil in four forms, Viz. Water soluble $\mathrm{K}$, which is taken up directly by plant; exchangeable - K, held

by negative charges on clay particles and is

\section{Introduction}

A Study was undertaken to evaluate the fertility status of Nignoti village, Indore district, Madhya Pradesh covering a village during 2013-2014. The systematic collection of samples in geo-referenced surface $(0-15 \mathrm{~cm})$ soils was done from 250 sites representing Vertisols and associated soils. The samples were analyzed for Mechanical composition of soil viz., Sand, Silt, Clay and chemical composition viz., pH, EC, O.M., and analyzed the different forms of potassium viz., water soluble $\mathrm{K}$, exchangeable $\mathrm{K}$, available non exchangeable K, lattice K, total K. The texture of the soils of Nignoti village of Indore district varied from clay loam to clayey which is neutral to slightly alkaline in nature and found normal in respect of soluble salts. Organic carbon status of Nignoti village was found in the range of $0.22-0.76 \%$ under different farmers field with the average value of $0.49 \%$. It is clear from the results, that more than half samples $(50.8 \%)$ of village show medium status and 47.6 percent soil samples show low status of organic carbon content in different farmer's field. The amount of water soluble, exchangeable, available, nonexchangeable, lattice and total-K in Nignoti village of Indore district; ranged from $0.008-$ $0.051,0.251-0.975,0.266-1.012,0.625-2.987,21.818-45.883$ and $23.515-49.640$ me $/ 100 \mathrm{~g}$ with the mean value of $0.019,0.550,0.569,1.463,32.522$ and $34.574 \mathrm{me} / 100 \mathrm{~g}$ respectively. Under different soil profiles, the water soluble, exchangeable, available and non-exchangeable forms of potassium decreased with depth. Whereas, total $-\mathrm{K}$ and lattice$\mathrm{K}$ did not show any define trend with depth. The exchangeable $\mathrm{K}$ showed significant and positive correlation with organic carbon content and clay particles of the soils. A highly significantly and positively relationship were observed between different forms of $\mathrm{K}$, These relationships indicate that there existed equilibrium between these forms of $\mathrm{K}$ and depletion of one is instantly replenished by one or more of the other forms of $\mathrm{K}$. available to plant; fixed $-\mathrm{K}$ which is trapped between layers of expanding lattice clays; and lattice- $K$ and integral part of primary $K$ bearing minerals The knowledge about different forms and availability of potassium is must while, studying the response of crops to potassium application. Because Potassium 
supply to crop plants is a complex phenomenon involving relationships among various $\mathrm{K}$ fractions in soil. Potassium availability to plants in general is governed by different forms of $\mathrm{K}$ viz., water soluble $\mathrm{K}$, exchangeable $\mathrm{K}$, fixed $\mathrm{K}$ and mineral $\mathrm{K}$. Plants utilize not only the readily available $\mathrm{K}$ but also the non-exchangeable and mineral $\mathrm{K}$ during the crop growth. The potassium availability to plants is determined by the rate of change in the dynamic equilibrium between different forms of $\mathrm{K}$ in the soil which in turn is controlled by the type of mineral, rate of weathering and exchange properties of the soil.

In Nignoty village of Indore district, potato is dominant crop keeping about $70 \%$ of the total cultivated area during rabi season. Potato crop requires more $\mathrm{K}$ than any others cereal and pulse crops. Since, there is no information available regarding the different forms of $\mathrm{K}$ and their inter relationship with some soils properties in soil of Nignoti village of Indore district.

Thus the present investigation is carried out with the following objectives to investigate the distribution of different forms of $\mathrm{K}$ in surface soil of Nignoti village, to investigate the vertical distribution of $\mathrm{K}$ in the soil profiles of Nignoti village and to collect the information on the fertilizer use pattern and cropping pattern of Nignoti village.

\section{Materials and Methods}

The village Nignoti is about $30 \mathrm{~km}$, towards north of Indore, which is surrounded by Bisenkheda in South, Kadwali in North, Jagmat Pipliya in East and Panod on the Western side. The region generally experiences hot, sub-tropical climate, having average rainfall of $800 \mathrm{~mm}$, with erratic pattern of distribution, mostly concentrated in the month of June to September, with very little amount from October to February. Over all 250 surface soil samples $(0-15 \mathrm{~cm})$ were collected from 250 different field of Nignoti village of Indore district, and their geographical position were recorded with help of GPS. The percentage of particles of different sizes that is sand, silt and clay was determined by mechanical analysis of soil. All the collected samples were analyzed by Bouyoucos Hydrometer method (1927). A 10 $\mathrm{g}$ soil was taken in a $50 \mathrm{ml}$ beaker to which 20 $\mathrm{ml}$ distilled water was added. The content was stirred with a glass rod for half an hour and equilibrium $\mathrm{pH}$ was determined by glass electrode $\mathrm{pH}$ meter (Piper, 1966).

To evaluate the depth distribution of $\mathrm{K}$ in soil profile sample were collected up to $75 \mathrm{~cm}$ with a interval of $15 \mathrm{~cm}$. Water soluble potassium was estimated in 1:5, soil: water suspension as described by Black (1965). The results were expressed in me $100 \mathrm{~g}^{-1}$. Exchangeable potassium was determined by flame photometer using $1 \mathrm{~N}$ neutral ammonium acetate extraction in 1:5 ratios as described by Black (1965).

The results were expressed in me $100 \mathrm{~g}^{-1}$. N boiling $\mathrm{HNO}_{3}$ extractable potassium was estimated flame photometrically in 1:10, soil: acid suspension boiled for 10 minutes as described by Black (1965) and the results were expressed in me $100 \mathrm{~g}^{-1}$. Total potassium was estimated flame photometrically by digestion with hydrofluoric (48\%) and perchloric (70-72\%) acid in platinum crucible by the method outlined by Black (1965) and the results were expressed in me $100 \mathrm{~g}^{-1}$ and estimated by difference between total $\mathrm{K}$ and sum of water soluble, exchangeable and nonexchangeable potassium.

The statistical analysis to understand correlation among different forms of potassium and with soil properties was done as suggested by Panse and Sukhatme (1961). 


\section{Results and Discussion}

In the present study, two hundred fifty surface soil samples $(0-15 \mathrm{~cm}$.) and five profiles were collected from Nignoti village of Indore district of western Madhya Pradesh and analyzed for different forms of potassium and for mechanical as well as physico - chemical characteristics. Water soluble $\mathrm{K}$ status of Nignoti village of Indore district of western Madhya Pradesh was found in the range of $0.008-0.051 \mathrm{me} / 100 \mathrm{~g}$ under different farmers field with the average value of $0.019 \mathrm{me} / 100 \mathrm{~g}$ and contributes only 0.015 to $0.24 \%$ of total $\mathrm{K}$.

Exchangeable K status of Nignoti village of Indore district of western Madhya Pradesh was observed in the range of $0.251-0.975$ me/100g under different farmers field with the average value of $0.550 \mathrm{me} / 100 \mathrm{~g}$, which accounted for 1.067 to $1.96 \%$ of total-K. Available K status of Nignoti village of Indore district of western Madhya Pradesh was noticed in the range of $0.266-1.012 \mathrm{me} / 100 \mathrm{~g}$ under different villages with the average value of $0.569 \mathrm{me} / 100 \mathrm{~g}$ and contributing to $1.65 \%$ of total-K. Status of non-exchangeable K under different farmers field of Nignoti village of Indore district of western Madhya Pradesh (Table 1) was found in the range of 0.625 $2.987 \mathrm{me} / 100 \mathrm{~g}$ with the average value of $1.463 \mathrm{me} / 100 \mathrm{~g}$ and contributed 2.66 to $6.02 \%$ of total K. Lattice K status of Nignoti village of Indore district of western Madhya Pradesh was found in the range of $21.818-45.883$ me/100g under different farmers field with the average value of $32.522 \mathrm{me} / 100 \mathrm{~g}$.

It is clear from results that the mineral pool of $\mathrm{K}$ is the main source of total $\mathrm{K}$ which accounts more than $90 \%$ of the total $-\mathrm{K}$. Total K status of Nignoti village of Indore district of western Madhya Pradesh was found in the range of 23.515 - $49.640 \mathrm{me} / 100 \mathrm{~g}$ under different farmers field with the average value of 34.554 $\mathrm{me} / 100 \mathrm{~g}$.
Vertical distribution of $\mathrm{K}$ in the soil profiles of Nignoti village is as follows: Five soil profile (up to $75 \mathrm{~cm}$ ) were exposed after harvest of different crop (i.e. Wheat, Gram, Potato, Onion and garlic) in Nignoti village and over all 25 soil samples were collected and estimated the different forms of potassium and their distribution pattern, which is given in table 4.6.

After harvest of different crops, surface soils samples of gram grown field show higher value of water soluble, exchangeable and available-K whereas, lower status were under Onion crop grown soils. Maximum value of non-exchangeable - $\mathrm{K}$ in surface soils was recorded with potato grown soils whereas minimum under wheat grown soils. Under different profiles, profile of garlic grown soils show higher value of total-K as compared to other crops, under different soil profiles, it is revealed from table 1 , that the water soluble, exchangeable, available and non-exchangeable forms of potassium decreased with depth. Whereas, total $-\mathrm{K}$ and lattice- $\mathrm{K}$ did not show any define trend with depth. However in most of the cases, total- $\mathrm{K}$ decreased up to $45 \mathrm{~cm}$ depth thereafter it increased and lower depth show higher status of total- $\mathrm{K}$.

\section{Correlation between soil properties and forms of potassium}

The results of correlation study (coefficient of correlation) between different forms of potassium with soil properties are presented in table 2.

Water soluble K status of Nignoti village of Indore district of western Madhya Pradesh was on the same line with different soil types have also been reported by Padole and Mahajan (2003) Chandrasekhara rao and Krishnamurthy (2007) and Mandal et al., (2011). 
Table.1 Vertical distribution of K (me/100g) in the soil profiles of different cropping pattern in Nignoti village

\begin{tabular}{|c|c|c|c|c|c|c|}
\hline Depth (m) & W.S.K & Ex. K & Avail. K & Non-ex. $\mathbf{K}$ & Lattice K & Total K \\
\hline \multicolumn{7}{|c|}{ Wheat } \\
\hline $0.0-0.15$ & 0.029 & 0.450 & 0.479 & 1.359 & 25.09 & 26.92 \\
\hline $0.15-0.30$ & 0.023 & 0.427 & 0.450 & 1.282 & 20.06 & 21.79 \\
\hline $0.30-0.45$ & 0.019 & 0.328 & 0.347 & 1.154 & 18.24 & 19.74 \\
\hline $0.45-0.60$ & 0.017 & 0.310 & 0.327 & 1.333 & 17.83 & 19.49 \\
\hline $0.60-0.75$ & 0.017 & 0.279 & 0.296 & 1.218 & 19.27 & 21.28 \\
\hline \multicolumn{7}{|c|}{ Gram } \\
\hline $0.0-0.15$ & 0.042 & 0.660 & 0.702 & 1.462 & 23.99 & 26.15 \\
\hline $0.15-0.30$ & 0.026 & 0.480 & 0.506 & 1.231 & 23.26 & 25.00 \\
\hline $0.30-0.45$ & 0.024 & 0.403 & 0.427 & 1.231 & 21.42 & 23.08 \\
\hline $0.45-0.60$ & 0.025 & 0.340 & 0.365 & 1.359 & 23.15 & 24.87 \\
\hline $0.60-0.75$ & 0.019 & 0.370 & 0.389 & 1.346 & 27.75 & 29.49 \\
\hline \multicolumn{7}{|c|}{ Potato } \\
\hline $0.0-0.15$ & 0.036 & 0.541 & 0.576 & 2.295 & 25.31 & 28.72 \\
\hline $0.15-0.30$ & 0.029 & 0.532 & 0.561 & 2.231 & 26.16 & 29.49 \\
\hline $0.30-0.45$ & 0.023 & 0.510 & 0.533 & 1.872 & 23.24 & 26.15 \\
\hline $0.45-0.60$ & 0.016 & 0.432 & 0.448 & 1.821 & 26.02 & 28.72 \\
\hline $0.60-0.75$ & 0.015 & 0.402 & 0.417 & 1.590 & 28.87 & 31.28 \\
\hline \multicolumn{7}{|c|}{ Onion } \\
\hline $0.0-0.15$ & 0.042 & 0.420 & 0.462 & 1.744 & 24.72 & 26.92 \\
\hline $0.15-0.30$ & 0.029 & 0.350 & 0.379 & 1.872 & 22.62 & 24.87 \\
\hline $0.30-0.45$ & 0.025 & 0.310 & 0.335 & 1.769 & 16.87 & 18.97 \\
\hline $0.45-0.60$ & 0.026 & 0.270 & 0.296 & 1.692 & 18.27 & 20.26 \\
\hline $0.60-0.75$ & 0.023 & 0.322 & 0.345 & 1.692 & 19.50 & 21.54 \\
\hline \multicolumn{7}{|c|}{ Garlic } \\
\hline $0.0-0.15$ & 0.038 & 0.485 & 0.523 & 1.949 & 34.71 & 37.18 \\
\hline $0.15-0.30$ & 0.029 & 0.434 & 0.463 & 1.590 & 34.36 & 36.41 \\
\hline $0.30-0.45$ & 0.023 & 0.414 & 0.437 & 1.410 & 38.41 & 40.26 \\
\hline $0.45-0.60$ & 0.021 & 0.299 & 0.320 & 1.410 & 35.96 & 37.69 \\
\hline $0.60-0.75$ & 0.016 & 0.244 & 0.260 & 1.308 & 37.41 & 38.97 \\
\hline
\end{tabular}

Table.2 Coefficient of correlation (r) between forms of potassium and soil properties

\begin{tabular}{|c|c|c|c|c|c|}
\hline & W.S.-K & Ex.-K & Nex.- K & $\begin{array}{c}\text { Lattice- } \\
\text { K }\end{array}$ & Total -K \\
\hline pH & -0.109 & $-0.279 *$ & $-0.197 * *$ & 0.054 & 0.011 \\
\hline E.C. & $0.214 * *$ & $0.236 * *$ & $0.181 * *$ & $0.164 *$ & $0.179 * *$ \\
\hline O. C. & $0.362 * *$ & $0.580 * *$ & $0.404 * *$ & $0.309 * *$ & $0.348 * *$ \\
\hline Sand & $-0.197 * *$ & $-0.370 * *$ & $-0.277 * *$ & $-0.195 * *$ & $-0.221 * *$ \\
\hline Silt & $-0.260 * *$ & $-0.411 * *$ & $-0.616 * *$ & 0.095 & $\mathbf{0 . 1 9 8 * *}$ \\
\hline Clay & $\mathbf{0 . 1 6 1 *}$ & $\mathbf{0 . 3 7 4 * *}$ & $\mathbf{0 . 7 9 2 * *}$ & $\mathbf{0 . 7 5 0 * *}$ & $\mathbf{0 . 7 5 2} * *$ \\
\hline
\end{tabular}


Kaskar et al., (2001) also reported that exchangeable $\mathrm{K}$ contributed $1.39 \%$ towards total K in soils. Kaskar et al., (2001), Padole and Mahajan (2003) and Mandal et al., (2011) also reported that available $\mathrm{K}$ contributed same line towards total K. Chand and Swami (2000) and Kaskar et al., (2001) also reported similar results with different soil type on the status of non-exchangeable $\mathrm{K}$ under different farmers field of Nignoti village of Indore district. Kaskar et al., (2001) and Padole and Mahajan (2003) also reported that lattice K contributed same line towards total K. Result on the same line with different soil types have also been reported by Padole and Mahajan (2003) for Total K status. The results for vertical distribution of $\mathrm{K}$ are in agreement with the findings of Raskar and Pharande (1997) and Singh et al., (2001). Electrical conductivity of soil showed significant positive relationship with all the forms of potassium. These results are in agreement with the findings of Tripathi et al., (1992). Positive and significant relationship between water soluble $K$ and exchangeable $K$ and as

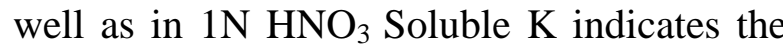
existence of dynamic equilibrium between these forms of K. Similar relationship were also reported by Chaudhary and Prasad (1997) and Das et al., (2000). Yadav et al., (1999), also reported that the exchangeable K show positive and significant relationship between $1 \mathrm{~N} \mathrm{HNO}_{3}$ Soluble and total $\mathrm{K}$. These results are in agreement with the findings of Mishra and Shrivastava (1991), Sonar and Patil (1996), Das et al., (2000), Singh et al., (2001), Sharma et al., (2009) and Jatav et al., (2014).

\section{References}

Black, C.A. (1965). Methods of soil analysis. Agronomy No. $\quad 9 \quad$ (2). American Society of Agronomy, Madison, Wisconsin.
Bouyoucos, G.J. (1962) Hydrometer method improved for making particle size analysis of soils. Agron. J. 54:464.

Chand, Subhas and Swami, B.N. (2000). Different forms of potassium in some important soils association of Bharatpur district of Rajasthan. J. of potassium Res. 16: 59-61.

Chandrashekhar Rao, C. and Krishnamurti, V. (2007). Quantity intensity relationship of potassium influenced Virgina tobacco soils of Khammam district Andhra Pradesh. J. Indian Soc. Soil Sci. 55 (2): 212-214.

Chaudhary, K. and Prasad, B. (1997). Distribution of different forms of potassium in alluvial soils of Bihar (India). J. of Potassium Res. 13; 3-4, 233-238.

Jatav, M. K., Manoj Kumar Dua, V. K. Sushil Kumar and Trehan, S. P. (2014).Distribution of different forms of potassium in potato growing soils of Jalandhar district of Punjab. International Journal of Agricultural and Statistical Sciences. 10 (1):175-179.

Kaskar, D.R; Salvi, V.G.; Mayekar, B.S. and Dabke, D.J. (2001). Froms of potassium their interrelationship and relationship with other soil properties of Inceptisols of west coast of Maharashtra. J. of potassium res. 17: 23-27.

Mandal, D; Dey, S. K. and Baruah, C. B. (2011) Forms of potassium and their distribution in rubber growing soils of Tripura. Ann. Pl. Soil Res. 13 (2): 7579.

Mishra, B.B.; Ghosh, S.K. and Ghosh, G. (1995). Studied of Potassium in soils Derived from Mica Rich Parent Material of Bihar I. Forms, Distribution and Fixation of Potassium in Soils. J. of Potassium Res. 11: 249-256.

Padole, V.R. and Mahajan, S.B. (2003). Status and release behavior of 
potassium in some swell-shrink soils of Vidarbha, Maharastra. J. Mah. Agric. Univ. 28: 3-7.

Panse, V.G and Sukhamte, P.V (1950). Statical Methods for Agricultural Workers. Publish by ICAR New Delhi.

Raskar, B.N. and Pharande, A.L. (1997). Different form of potassium and their distribution in some important soils series of vertisols and alfisols of Western Maharastra. J. of potassium Res. 13 (1): 21-30.
Tripathi, D., Upadhyay, G.P; Bhandari, A. R. and Sharma, U. (1992). Potassium distribution in some orchard soils and Mandi district of Himachal Pradesh. $J$. of Potassium Res. 8 (3): 264-267.

Yadav, N.S., Verma, R.S., Trivedi, S.K. and Bansal, K.N. (1999).Vertical distribution of forms of $\mathrm{K}$ in some soil series of Vertisols of M.P. J of Indian Soc. Soil. Sci. 47 (3): 431-436.

\section{How to cite this article:}

Jitendra Kumar Panwar and Shila P.K. Unni. 2018. Status and Distribution Study for Different Forms of Potassium in the Soils of Nignoti Village of Indore District of Western Madhya Pradesh, India. Int.J.Curr.Microbiol.App.Sci. 7(04): 1579-1584.

doi: https://doi.org/10.20546/ijcmas.2018.704.177 